\title{
The concept of Den'gi (Money) in the St. Petersburg population at the beginning of the 1990s"
}

\author{
Renate Rathmayr ${ }^{* *}$
}

Social change brings about discursive change. Particularly, it causes shifts of meaning within the key concepts of social discourse. The concept of den'gi (money) has undergone fundamental alteration in Russian language and culture since perestroika. This conceptual change will be discussed in the following article. My findings are based on a corpus of interviews recorded in St. Petersburg in 1993. The concepts compared, i.e. the concept of den'gi before and after perestroika, respectively, can only be sketched out roughly here. The interviews conducted in 1993 reveal conflicting discourses on money that are rooted in Russian, Soviet-Russian - the traces of the minor role money played in the Soviet era were still present in social discourse in 1993 - and free enterprise ideologies, respectively. They also reveal that by that time a clear tendency towards a concept of money oriented by market economy had already emerged, at least among the younger urban population.

Gesellschaftliche Veränderungen verändern Diskurse und insbesondere ihre Schlüssel-konzepte. Das Konzept den'gi (money) hat im Russischen nach der Perestroika eine gewaltige Veränderung erfahren. Worin diese besteht, wird im Beitrag anhand eines Korpus von Interviews, die im Jahr 1993 in Sankt Petersburg aufgezeichnet wurden, nachgezeichnet. Die beiden zur Kontrastierung herangezogenen Konzepte bzw. Epochen vor und nach der Perestrojka können in diesem Rahmen nur ansatzweise skizziert werden. Die Interviews des Jahres 1993 zeigen die Präsenz der widerstreitenden Diskurse über Geld, die ihre Wurzeln in der russischen und russisch-sowjetischen - die Spuren der geringen Bedeutung von Geld in der Sowjetzeit sind deutlich präsent - sowie marktwirtschaftichen Ideologie haben, und deutlich in die Richtung der Durchsetzung eines marktwirtschaftlich orientierten Konzepts den'gi zumindest für die jüngere Bevölkerung der Großstädte weisen.

Key Words: Linguistic concepts / Linguistic change / Discourse analysis / Language and society / Russian language

\footnotetext{
* Manuscript received: 02.07.03, revised: 22.12.03, accepted: 08.01.04

**Renate Rathmayr, born 1947, head of the Department of Slavic Languages (full professor) at the Vienna University of Economics and Business Administration. Main research topics: Russian language, linguistic pragmatics, intercultural communication, business Russian. Corresponding address: renate.rathmayr@wu-wien.ac.at
} 


\section{Introduction}

The word den'gi (money) entered the Russian language "from the East" (most likely of Turkish origin), not before the latter half of the thirteenth century (Stepanov 2001:562-3). The denotative meaning of the word den'gi has been stable for a long time, a fact illustrated by the explanations given in any dictionary, for example, the entry in the encyclopaedia published during the Soviet era, and in the economics dictionary published in the second half of the nineties: "a specific good that fulfils the role of a general medium of exchange that expresses the value of all goods" (Énciklopedičeskij slovar' 1963:321), "a special type of universal good, used as a general medium of exchange to express the value of all other goods" (Rajzberg et al. 1996:76). ${ }^{1}$

A term so central to society as den'gi, however, does not consist in its denotative meaning alone, i.e. the relationship between word and nonverbal entity; it rather represents a "concept" - a "founding cell of the culture in the mental world of a person" (Stepanov 2001:43). In the theory of cognitive linguistics, concepts are mental depictions of reality that structure our perception and our knowledge of the world in all its inherent facets. ${ }^{2}$ Concepts, therefore, combine individual and social perceptions. The majority of concepts, albeit not all of them, correspond to words present in natural language. The lexical meaning, which more or less corresponds to its dictionary entry, primarily determines the reality that the given word describes, roughly constituting people's linguistic consciousness of the word's possibilities in use. Encyclopaedic information, positive and negative connotations and world knowledge constitute additional components of the concept over and above its lexical meaning. A concept's elements can easily vary in specific statements, with each respective speaker emphasizing one or another element, depending on his/her world knowledge, and no less important, a concept is a dynamic phenomenon: when the value attached to the phenomenon it denotes changes, the concept changes along with it.

The social and economic changes occurring in Russia since the era of perestroika can therefore be expected to have changed the concept of den'gi. These changes relate, on the one hand, to the physical reality of money - i.e. notes, coins and prices of goods and services, and, on the other hand, to the way people relate to money. During Soviet times, notes and coins did not change for

\footnotetext{
${ }^{1}$ Both quotations are only the beginning of the dictionary entry for den'gi. Translation of quotations from Russian sources by R.R throughout the text.

${ }^{2}$ The definition of concept used in this context corresponds to the interpretation developed in the project "Key concepts of market economics". In addition to the author of this article, U. Doleschal, E. Hoffmann, B. Müller and J. Petters participated in the project (c.f., for example, Rathmayr 2004a.b; Müller, Petters, Doleschal 2002). The project was financed by the Austrian National Bank.
} 
decades, fares for public transport remained stable throughout a whole generation's lifetime, and the prices of many products were simply printed onto the packaging. The population had little money, but money was not crucial to securing privileges: if people felt there was a deficit, it usually meant that both goods and money were in short supply.

All this changed radically a few years ago. New notes and coins were launched several times; on January 1, 1998, three zeros were knocked off the rouble. The system of prices that emerged in the USSR at the beginning of the era of economic reform contained a myriad of "distortions", i.e. the prices of some product types were substantially lower than production cost, whereas the prices of other products far exceeded the product's actual cost (c.f. Afanas'ev/Ferro 1989:287). The process of establishing market prices was accompanied first and foremost by incessant price hikes affecting the majority of goods. The galloping inflation of 1992 in Russia is generally known: wholesale prices rocked 2000 $\%$, retail prices soared $2500 \%$, but wages did not follow suit. A family's real income fell by one half within the space of a month, which meant that $50 \%(90$ $\%$ for pensioners) of the family budget went on food (c.f. Oppermann 2001). The voucher system was introduced against this backdrop in October 1992. As a result, money suddenly became vital to Russian society in 1993 as the means of "feeding the family". The absence of money in several social strata gave rise to real poverty. Take pensioners by way of example, who could not even afford bread on their pensions.

We can assume that these socio-economic changes radically altered people's relationship to money, an assumption that will be substantiated below by an analysis of authentic oral discussions about money that took place in 1993. As the concepts emerge in the discourse, conclusions about the concept can be drawn on the basis of the interview texts analysed and the generalisation in expressions containing den'gi. These discussions are used as a basis to reconstruct the concept of den'gi prevailing among those asked at the time, who were people of different social groups (see chapter 2). It should be mentioned that this paper does not intend to explore the economic concept of den'gi in the professional context.

Firstly, the corpus of texts used and the method of analysis are outlined. In the main part of the paper, collocations ${ }^{3}$ of all the uses of the word den'gi in the statements made by respondents are analysed, the objective being to identify the concept prevalent among the respondents. I will briefly demonstrate the

\footnotetext{
${ }^{3}$ The term collocation contains both the addition of attributives and the link between subject and object, the relations between words in various contexts. The professional discourse would certainly give rise to a different set of collocations for example, gorjačie den'gi (from the English hot money), dlinnye den'gi (long),korotkie den'gi (short), dorogie den'gi (expensive), nedorogie (cheap) etc.
} 
approach of collocation analysis, which in a further step will serve as the basis of thematic focussing in a discursive analysis of excerpts selected from the interviews. In order to give an adequate interpretation of the concept prevalent in 1993, it will be contrasted to that of the Soviet era, on the one hand, and to the way the concept has developed in the course of the past ten years, on the other. Of course, these latter concepts of den'gi can only be briefly sketched out here.

\section{Corpus of texts and method of analysis}

The empirical basis of the study is a corpus of oral interviews, recorded at the beginning of the nineties in St. Petersburg. Sociologists at the University of Helsinki in Finland initiated the project ${ }^{4}$. The interviews were, however, conducted by Russian sociologists. According to the Finnish sociologists, the purpose of the interviews was to reveal a complete picture of the daily life of the 100 families questioned, and to describe the survival strategies they selected to cope with the economic crisis at the beginning of the nineties. (c.f. Piirainen 1997: 42-46). The subject of money was not the direct goal of this sociological study. However, it is significant that the survival strategies were to a great extent linked to the presence of money. This enables the recorded material to be used to explore the concept of money, the subject being analysed in my paper. The interviews were not tightly structured, but mainly took the form of free conversations not limited in duration. So far, 16 of the interviews with Russian native speakers recorded in 1993 have been transcribed at the University of Tampere, under the supervision of Maria Leinonen. They were also used as the basis for this study. The sample, therefore, is not yet wholly representative. Nevertheless, the age groups represented range from 30 to 70 . The majority of respondents have completed higher education, a few only with secondary education. Had these interviews been conducted in provincial Russian towns, the results would undoubtedly have been different, as the analysis highlights the situation in 1993 in St. Petersburg. This could perhaps also be typical of other large cities in Russia.

In the interview corpus consisting of 151,047 word-forms (tokens), the following frequencies of repetition of the word den'gi were noted - by the way, $d e n ' g i$ was the most frequently cited auto-semantic (i.e. not purely structural such as conjunctions, articles etc.) word, used 356 times. The word is used both by respondents and by the interviewers themselves, but more frequently by the

\footnotetext{
${ }^{4}$ The sociological project "Structural Change and Survival Strategies: Adaptation to Market Relations in Russia" was set up under Professor Jussi Simpura. The interviews were conducted from 1993-96 with 100 families in St. Petersburg, 20 of which were interviewed once again 2-2.5 years later. The sample of respondents is as representative as possible (c.f. Piirainen 1997:46).
} 
respondents - interestingly in contexts where the sociologists had asked about something totally different - e.g. whether the respondents went to the theatre or the cinema (see below). The first stage of the empirical analysis involved analysing the collocations. Attributives and verbal constructions were allocated to content groups. Statistical and semantic aspects of the collocations used were analysed.

After analysing the context of the collocations, the selected sequences containing the word den'gi were analysed using discursive analysis. To be more precise, the method used was "critical discourse analysis", which examines communication in its historic and social contexts and emphasises the dialectical links between language and social conditions (c.f. Wodak 1995; Van Dijk 1998; Fairclough 1989, 1995; Fairclough/Wodak 1997). This analysis consists of the following stages: assertive and desiderative expressions in the texts are differentiated. Next, thematic aspects are examined: rhetorical and pragmatic strategies such as metaphors, mitigation and hedging, direct and indirect judgements etc. are analysed. The last stage of the study entailed taking into consideration the respondents' thought mechanisms, prerequisites, presuppositions and general convictions to identify text meanings that are not evident (c.f. Fairclough 1989:79). Knowledge, opinions, and attitudes expressed in discourse and in other social practices are transformed into conditions and convictions, which are general and common to a certain group of people. These conditions and convictions develop in and through discourse, on the one hand, and in turn, they influence the discourse prevalent in society. Thanks to the interplay of these processes, discursive analysis can be used to draw conclusions about existing and - at times - competing convictions in society, about levels of knowledge, objectives and prevalent attitudes. Thus, although the individual accounts of living conditions respondents give in the course of an interview are shaped by their individual and unique identities, respondents still resort to patterns of interpretation made available by the specific society they live in.

Every individual text is regarded as an example of a whole class of similar texts, for an individual in her/his interpretations, explanations, justifications and argumentations draws on the socially available stock of ideological assumptions, attitudes, opinions, „myths“ as defined by R. Barthes (1964), „socially shared beliefs“ as defined by Teun van Dijk (1998). From that point of view, it is perfectly justified to draw conclusions from a restricted corpus of texts by way of structural validation, which hold until they are refuted by new findings (principle of falsification).

Due to the lack of similar material from another period, no systematic comparison with the concept of den'gi prevalent in previous periods was possible. To illustrate the dynamics of the concept's development, however, we can make some general observations on the frequency and thematic nature of 
the discourse in earlier corpora. The texts of the Uppsala corpus, collected between 1960 and 1988 and comprising 832,986 words $^{5}$, were clearly not devoted to the subject of survival. Therefore we can expect the word den'gi to occur with a much lower frequency. In fact, this hypothesis is confirmed with 163 utterances of the lexeme den'gi. Irrespective of the different genres and subject matter of the material compared, it is nevertheless significant that in the corpus "Russkaja razgovornaja reč'. Teksty" (Barinova, Zemskaja et al. 1978), the frequency of the lexeme den'gi can be observed (from 34,862 word-forms, the lexeme den'gi occurs only six times). This finding does not imply that the subject of money was absent in the language of the time; however, the figures do show that the texts in question illustrate a certain degree of social stability in contrast to the St. Petersburg recordings during the economic shock. In order to roughly sketch out the development of the concept den'gi after 1993, in my discussion of selected research questions I will also draw upon my observations concerning the mass media as well as interviews conducted in October 2003 in Moscow.

\section{Analysis of collocations}

\subsection{What types of den'gi (money) are there? Attributes}

\subsubsection{Quantitative characteristics: you need a lot of money, but you never have enough}

The most important qualification of money is quantity. It is interesting to note that respondents tended to qualify only large amounts of money that either they themselves required or that somebody else was demanding from them. ${ }^{6}$ One direct quantifier is used in the expression: Očen' mnogo deneg uchodit na pitanie (a lot of money goes on food). The combination bol'šie den'gi (lots of money) occurs seven times in the corpus, but the respondents do not have lots of money, they just need lots of it. Bol'šie den'gi is in fact the first and most frequent association with the stimulus den'gi (money) given in the first volume of the Russian dictionary of associations (Karaulov et al. 1994:43), the corpus of which was primarily compiled at the same time as this analysis (from 1989 to 1991).

Emotional values are far more frequently attached to large sums of money which the respondents do not have. Lots of money is expressed by carskie (tsarist) or chorošie (good) money, and in some interviews, large sums of

\footnotetext{
${ }^{5}$ The corpus contains journalistic texts from 1987-88 and fiction published from 1960 to 1988 .

${ }^{6}$ The subject was considered with quotes (verstehe nicht, was das heißt) from original examples from the corpus in Rathmayr (2004b) written in Russian. Abridged examples only are integrated into this text.
} 
money belonging to others are expressed using hyperbole characteristic of colloquial speech to describe quantities beyond generally accepted dimensions and perceptions, for example: sumasšedšie (insane), žutkie (terrible), obaldennye (crazy). Such assessment of other people's money corresponds with the general opinion that you cannot earn lots of money by honest means.

The specific measurement of money was given with the help of amounts given in roubles. Various forms of the lexeme rubl' occurred 112 times in the corpus, with the constructions generally being formed with numerals - there are only 3 exceptions to this (štrafnye rubli - fines, ni rublja-broke, ne nužno do rublja). In almost all the interviews, respondents were asked what amount of money they would need "to live a normal life", "to live a free life". The respondents generally found it difficult to name a specific sum, not least due to the instability of the national currency and to inflation. Therefore, specific objects are often cited as a substitute - i.e. chocolate bars, juice etc. Many formulated their idea of "living normally", where components such as living comfortably in financial terms, trips abroad, orange juice every day were cited as symbols of a new, good life.

Quantitative judgements are implicitly expressed in combinations of the type: na èti den'gi nakormit' sem'ju nevozmožno (you can't feed a family on this amount of money). Phraseological expressions are used as a means of indirectly judging quantity, for example: Čto èto za den'gi dlja devčonki - What a pittance for a young girl! ("You are kidding, aren't you?") and Razve èto den'gi? - Is this supposed to be money? Both phrases describe a small, inadequate amount. Impersonal verbal constructions chvataet / ne chvataet deneg na čto-nibud' - the money is enough / not enough for something are used to express whether or not the amount of money available is adequate - usually it is not. In almost all interviews we see that clauses of statement generally provide information about negative situations triggered by the absence of money or by a lack of sufficient funds, whereas desiderative expressions describe the desire to possess more money.

\subsubsection{Classification of money by origin, by ownership and other characteristics}

Money is judged morally in connection with its "origin": normal'nye (normal), normal'nye čestnye (honest), naši zarplatnye (our earned), nakoplennye (accumulated), sobstvennye (our own), - these words denote good money chorošie den'gi (good money), whereas tenevye (shady) - denotes bad money. Neutral attributes of a nominative nature are blokadnye ${ }^{7}$ (siege money), bjudžetnye (budgetary), municipal'nye (municipal) money.

\footnotetext{
7"Siege" money denotes state subsidies given to people who survived the Leningrad siege.
} 
The following characteristics of money can also be found: živye (living, meaning money you actually own, which really exists, which can be readily used), svobodnye (free) money, which can be spent, which can be freely disposed of, naši (our) money, i.e. Russian currency) and ostal'nye (other) money. Takie (this) and drugie (that) money denotes money which is considered "unstable", for example: segodnja takie den'gi / a zavtra drugie (today it's this money / but tomorrow it's that money).

\subsection{Money in actions: Verbs}

\subsubsection{Presence / absence of money (to have money / to want to have money)}

With very few exceptions (see 3.2.3.), the subject of actions involving money is invariably the respondent himself/herself. The presence or absence of money is described with the help of the neutral verb to have. Respondents far more often describe the necessity of having money nužny, ponadobjatsja den'gi (to need money). The expression den'gi ne problema (money is no object) does not refer to the respondent, but rather to a third person. When referring to his/her own situation, the respondent says that trudno $s$ den'gami, plocho $s$ den'gami (the money situation is bad/difficult). And if money is available, it's never enough.

It can be noted that there are stereotypical perceptions of a psychological nature about money, which cannot be linked to a specific period of time (deneg est' malo, a otdaeš' mnogo -you have little money, but you spend a lot). They are reflected in common expressions like Svoich deneg vsegda ne chvataet (Your own money is always scarce); $V$ dolg bereš' čužie na vremja, a otdaeš' svoi navsegda (You borrow someone else's money for a certain time, but you pay back your own for ever) etc.

\subsubsection{Respondents' actions with money}

Respondents describe the actions they undertake to obtain money in two ways:

- actively: delat'/ sdelat' / (make), dostat', zarabatyvat' (ceбe) (earn), vzjat' (take), nažit' chorošie den'gi (to acquire good money), gonjat sja za den'gami (to chase after money);

- and being on the receiving end: ich polučajut (they get it), pojdeš'polučat' (you begin to get ..), platjat (mne den'gi)(they pay me money), mne dadut (they give me), dajutsja (it is given), vydeljajut (they provide). Sometimes money is sought (iščut) and found (najdut) or is taken (berut) for a certain period of time: zanimat'/ zanjat' den'gi u kogo - to borrow money from someone.

As a rule, money, once in the hands of the respondent, does not remain there long. They give it away in exchange for some sort of goods - platit'/zaplatit' (to pay), vyplačivat', tratit'/ istratit' (to spend), dat' za čto (give/spend on something). If a large sum of money is spent on something, money is said to 
evaporate - raspyljat' den'gi. Money can facilitate other transactions. Some interviews describe the process of giving away money as an involuntary activity. The use of the verb otstegivat' (to unfasten) is interesting in this context: den'gi tol'ko prichoditsja otstegivat', napravo i nalevo - you constantly have to give money away (unfasten) - in all directions (left and right). Money is used to buy food, and it became impossible to feed one's own family and to survive under the changed conditions with èti - this - money, i.e. not enough: na èti den'gi nam ne prožit' - we can't survive on this money; na èti den'gi nakormit' sem'ju nevozmožno - it's impossible to feed the family with this money.

Money can also be earmarked - vydelit', lent - dat' komu-nibud' v dolg, deposited - na chranenie or used to run the household - vedenie chozjajstva: it can be handed over - otdavat'/ otdat' (to the husband or wife), it can be given away as a gift - poslat', prisylat' (from father to daughter) and it can be used to help someone - usually relatives - pomogat', okazat' pomošč'. Money can also be saved up, invested, put somewhere, or put into circulation - nakopit', vkladyvat'/ vložit', položit' kuda-nibud', zakručivat' (used colloquially to mean putting money into circulation for one's own gain) to increase the overall sum. In addition to receiving and spending money, only a few other types of activities are described in terms of money: ich rasčityvajut / sčitajut / o nich vedut razgovor (money is counted or talked about).

\subsubsection{Other peoples' dealings with money}

The agent of the action involving money is not the respondent in only seven examples, most of which concern the State. In these cases, respondents usually take the position of object - the source of money for the State. For example: vveli svoi den'gi/svoju valjutu - they issue money / foreign currency, oni berut/ zabirajut s nas vse den'gi - they take all our money, These examples also illustrate the concept of the State, which could equally be the subject of closer examination.

In the eyes of the respondent, the implied "culprit" of the very expensive medical and social services of all kinds is generally considered to be the State, and only in rare cases, it's the private sector that is put the blame on.

\subsubsection{Money conceptualised as an "active subject" (What does money itself do?)}

Money is around somewhere or is on the move or even changes its quantity. So money is in the respondent's possession or is heading towards or away from him/her: money is kept - den'gi ležat, it appears - pojavljajutsja, went somewhere - pošli kuda-nibud', goes into my pocket - idut ko mne v karman, money disappears - den'gi uchodjat, money is spent on something - idut na čto-nibud', den'gi byli v oborote v kommerčeskich strukturach-money was in 
circulation in commercial structures, den'gi vozvraščajutsja - money is reimbursed.

In four interviews, money is said to change itself, i.e. implying that the quantity of money changes of its own accord: on the one hand, money loses its value, becomes worthless (terjajut svoju cenu, prevratilis' $v$ nol'), on the other hand, money begins to work - načinajut rabotat' or even begins to multiply - sami zarabatyvajut sebe den'gi.

\section{Discursive analysis of selected sequences, illustrating key components of the concept}

\subsection{Subject: everything has become too expensive and the absence of money is the main reasons for all current problems}

Respondents feel that not having enough money to fulfil their basic needs is a humiliating catastrophe and money is considered central for the person's selfesteem. One female respondent put it as follows: kogda nechvatka sredstv, čuvstvuešs' sebja čelovekom vtorogo sorta - the shortage of means makes you feel a second-rate person. ${ }^{8}$ Generally speaking, respondents usually answer questions referring to their quality of life by listing problems of a material nature (c.f.: my problems all stem from the fact that I have no money svjazyvaju svoi trudnosti s tem čto deneg netu; c.f. Rathmayr 2004b).

The lack of material means, i.e. the absence of money as a consequence of socio-economic changes and an unstable society is unanimously considered by all respondents to be the main reason for the poor quality of life and bad current situation (c.f. Rathmayr 2004a). If the interviews are read without bias, the reader could gain the impression that the USSR was a paradise for consumers. Nevertheless, one family points out that there were problems back then as well, but that at least na èti den'gi možno bylo chot' nakormit' sem'ju (you could feed the family with the money you had).No matter what the subject, everything comes down to a lack of money. In all the interviews, complaints were made about high prices for perfectly ordinary foodstuffs that were easily affordable before, such as chocolate for 2 roubles. Nowadays, the chocolate is so expensive that it really hurts the soul - duša bolit. If conversations about the cinema or the theatre were commonplace among Russians in the seventies (c.f. the corpus "Russkaja razgovornaja reč" Barinova, Zemskaja et al. 1978),

\footnotetext{
${ }^{8}$ It is interesting that, a few years on, the current Russian president, Vladimir Putin, has cited this very task as one of his core objectives. His main aim over the next three to four years is to bring about a noticeable improvement to the material situation of every Russian citizen, to provide security and to improve their quality of life, to make people "proud of their country" (Interfax News Agency (Russian Language), Daily News Bulletin (Russian Language) 19/07/2001).
} 
respondents in 1993 react to the question as to whether they are interested or participate in cultural life, generally, by saying that they have no money for such things and by complaining that market forces in the field of culture are abhorrent - rynočnye otnošernija vobalsti kul'tury - užasnoe javlenie.

The focus on the material side of life is no coincidence and is not only a consequence of the terrible inflation at the beginning of the nineties, it clearly confirms the assumption made by a number of academics, namely that the process of economic globalisation would be accompanied by a shift in a society's focus to economic aspects of life. At the same time, another wellknown hypothesis is also confirmed; the members of a society require a minimal material basis to enable them to satisfy their spiritual needs. In order to make out the traces of "transformation" in these discourses one must keep in mind that at the beginning of the 1990's, when the interviews were conducted, it was obviously not embarrassing to speak about money any more. But it was embarrassing in Soviet times. And if we think about the situation ten years later, in 2003, we can see that speaking about money has become quite normal, there is even a magazine named "Den'gi" (Money) ${ }^{9}$, containing a column titled "Dlja tech kto ljubit den'gi“" (For those who love money). At the same time, according to several observations and interviews the topic "lack of money" has become less frequent than it was in 1993.

How can we explain that money has stopped to be a taboo topic and the Soviet era with its permanent shortage of goods has almost come to be glorified? This raises the question about the traditional Russian attitudes towards money. We assume that people generally held an "ambivalent" attitude towards money in traditional tsarist and Soviet Russian culture. Stepanov explicitly refers to "Russian" culture without differentiating between Russian tsarist and Soviet culture, this terminological confusion not being Stepanov's idiosyncrasy, but a typical feature of the process of identity construction going on in post-Soviet Russia, amalgamating the Soviet and the Russian era in a "patriotic consense" (Simon 1997) as if there had never been any rupture in the country's history. According to Stepanov (2001:560), the attitude to money was indeed "one of the most clearly discernible psychological traits in Russian culture". Money, as with all things "superficial" in general, was in Russian tradition contrasted with the spiritual, intellectual world, which was deemed infinitely more valuable. There are many phrases and sayings to illustrate this, for example: $N e v$ den'gach sčast'e (You can't buy happiness); Pusti dušu v ad, budeš'bogat (You will get rich if you send your soul to hell); Grechov mnogo, da i deneg vvolju (There are many sins, one being money in abundance); Bogatyj-to s rublem, a bednyj-to s lbom (literally - The rich man turns up with his roubles, the beggar with his forehead) (Dal' 1984:57 ff). It is true that the Soviet era was

\footnotetext{
${ }^{9}$ The magazine was founded in 1997 by the publishing house „Kommersant““
} 
characterized by a permanent shortage of goods, but the goods that were available in the shops were absolutely affordable to the majority of the population. So the experience of seeing foodstuffs on the shelves of shops and supermarkets one would want to buy but cannot is absolutely new and painful.

\subsection{Subject: moral assessment of the relationship to money}

The basic characteristics of the concept of den'gi correspond to the explanations in the dictionary, i.e. money as a universal means of exchange. You have to have money to buy specific goods and generally to survive. The status of money as a general means of exchange is reflected in various constructions: things are done for money, money is spent on obtaining something, money is spent on helping others, or someone sends money to help: papa posylaet den'gi (daddy sends some money).

The moral judgement of people's relationship to money seems to be the subject that most clearly exposes the conflicting discourses. During the Soviet era, there was clear differentiation between the negative perception of capitalist monetary policy, whose purpose was to exploit labour, and the sensible stance of socialist monetary policy, lending "stability to the socialist monetary system" (See Enciklopedičeskij slovar' 1963: 321). The rather negative attitute towards money that Stepanov states to be typical of the Soviet era as mentioned above is expressed by a 55-year-old woman quite explicitly. She talks about the fact that her generation did not work for money, but for the idea - rabotalo ne za den'gi, a za ideju. The same typical Soviet stereotype is reflected in some respondents' talk about their not being able to take any money for their services. So, for example, a naturopath says: ja za den'gi ne leču, prinesut rebenku jabloki ili pečenie (I don't heal for money, they bring some apples or biscuits for the child). As an interview partner put it in 2003: all those born before 1970 got "the Soviet vaccination" (s sovetskoj privivkoj), which means that for them the most important human qualities are moral ones (samoe glavnoe, čtoby čelovek byl chorošij).

In contrast a new, emerging principle of social behaviour is revealed in another interview: anything for money - vse dlja den'gi. The respondent complains that the service provided by the housing administration has become worse, even though it is no longer free of charge. The respondent's conclusion that people do a bad job even when paid for it - daže za den'gi plocho obsluživajut is supported by the sociologist conducting the interview. However, greed - when someone is even prepared to kill for money - is condemned by those interviewed.

The realisation that money really is a means of exchange is a feature of the new Russian society. Texts discuss the fact he/she who has money not only can buy anything, he/she also has power. This final aspect is a phenomenon new to Russian culture. In one of the interviews, the respondent criticises trading 
practices in small shops/kiosks, where everything is sold on at higher prices. The speaker, a military man with a university education, who teaches at a university, thinks that the biggest political mistake was to permit cooperatives to operate in the retail trade, but not in manufacturing. This mechanism enabled many to get rich very quickly and those who have money, have power - $u$ kogo den'gi u togo vlast' and when you have lots of money, you can buy anything est' mnogo deneg možno vse kupit'. My personal observations and contacts, a number of interviews conducted with Russian people in Oktober 2003 in Moscow and articles in the mass media have shown that ten years later the stark contrasts that characterized discourse at the beginning of the 1990's have been displaced by a general acceptance of the role of money in a market economy; money as a topic has stopped to be embarrassing and it has become increasingly normal to take money for one's services.

\section{Conclusions}

This article describes the current concept of den'gi (money), as observed among the St. Petersburg population in 1993. The arguments and the repeated desire to have more money, which was observed in almost all the interviews, clearly reflects the importance of money in the emerging market economy. Still, the traces of the limited importance attached to money during the Soviet era are clearly discernible. Statistical analysis of the frequency of use of the lexeme den'gi unequivocally confirms how important money is. Den'gi, which among 151,047 word-forms was the most frequently used lexeme (356 citations), and the additional interpretative analysis of these interviews provide further evidence. The high frequency of the lexeme den'gi depends to a certain extent on the topic under discussion: the most important questions posed by the interviewer referred primarily to material aspects of family life. The analysis revealed that over the time period analysed, money in reality and the concept of money have undergone fundamental changes. Our observations are in line with the results of surveys conducted in 1995 to 1996 among the population of a number of large and small towns in Russia, which also reaffirmed the importance of the concept of den'gi (Fleischer 1997).

The following features of the concept of money were identified in the analysis of collocations:

- The following types of money are highlighted: živye ("living"), svobodnye (free), svoi (one's own), čužie (someone else's), but the main feature of money is its measurability. Money is required to satisfy fundamental material needs, to live well - žit' chorošo and even to ensure survival - vyžit', not as a prerequisite for a certain social status.

- Money is a concept that is judged from a moral perspective: čestno zarabotannye (honestly earned), tenevye den'gi (shady money). People 
are suspicious of an adequate supply of money because it is generally believed that large sums of money cannot be obtained by honest means.

- Money is conceptualised as an object that the respondent or other subjects use to carry out a certain inventory of actions: den'gi zarabatyvajut (money is earned), tratjat (spent), čtoby polučit' čtonibud' vzamen (to get something in return), less frequently to deposit it in the bank - vložit'v bank. The State issues money, pays money-vvodit den'gi, platit den'gi, but mostly takes it away - zabiraet den'gi from its citizens.

- Money is conceptualised as an active, personified subject: oni prichodjat, uchodjat, pojavljajutsja, isčezajut, prevraščajutsja v nol' - it comes, goes, is there, disappears into thin air.

Money has become indispensable as a prerequisite to a normal life and in the era of post-perestroika economy, new value systems are gradually emerging, particularly among young people. Stepanov (2001:561) states that the traditional attitude of "Pomogi bednym" (helping the poor) is being replaced by a "vtoroj mentalitet" (second mentality): "Možeš' ubit' konkurenta" (You can kill the competition). The call for altruistic behaviour is wholly absent from the second mentality, according to Stepanov, it therefore makes sense to earn as much money as possible, by whatever means. In my view, this has less to do with a change of moral standards, but more with the opportunities presented by the new economic order: under socialism, even a really large sum of money did not enable one to fulfil such desires as trips abroad, new cars or even imported furniture. Nowadays, money makes all this possible, you can buy all the things that were available only to the privileged nomenclature under socialism. In the last few years, the "rasčetnaja psichologija" (calculating psychology), particularly apparent among young people, has become a normal social phenomenon. Today's young people look for "creative" work and want to receive "normal" remuneration in return. The negative moral assessment of material wealth as formulated in many interviews especially by representatives of the generation over 35 roots in the high moral assessment of immaterial values in Russian traditional as well as in Soviet culture. The interviews conducted in 1993 reveal conflicting discourses on money, which are rooted in Russian and Soviet-Russian ideologies as well as in market ideology, with a noticable tendency towards a market economy concept of den'gi clearly gaining acceptance, at least in the big cities.

\section{References}

Afanas'ev, J./Ferro, M. (eds.) (1989): Opyt slovarja novogo myšlenija. Moskva.

Barinova, G.A./Zemskaja, E.A. et al. (1978): Russkaja razgovornaja reč'. Moskva.

Barthes, R. (1964): Mythen des Alltags. Frankfurt/Main. 
Dal', V. (1984): Poslovicy russkogo naroda. T. 1. Moskva.

Van Dijk, T. (1998): Ideology. A Multidisciplinary Approach. Tousand Oaks et al.

Énciklopedičeskij slovar' v dvuch tomach. T. 1. Moskva 1963.

Fairclough, N. (1995): Critrical Discourse Analysis. The Critical Study of Language. Harlow.

Fairclough, N. (1989): Language and Power. New York.

Fairclough, N./Wodak, R. (1997): Critical discourse analysis. In: T. van Dijk (ed.) Discourse and Interaction. Thousand Oakes et al., 258-284.

Fleischer, M. (1997): Das System der russischen Kollektivsymbole. München.

Karaulov, J.N./Sorokin J.A./Tarasov, E.F./Ufimceva, N.V./Čerkasova, G.A.: Russkij associativnyj slovar'. T. 1. Moskva 1994.

Müller, B./Petters, J./Doleschal, U. (2002): Die Diffusion marktwirtschaftlicher Schlüsselkonzepte in Mittel- und Osteuropa: Eine linguistische Analyse. In: Forschungsservice der Wirtschaftsuniversität Wien (ed.): Wirtschaftsuniversität Wien - Jahrestagung 2002 "Forschung für Wirtschaft und Gesellschaft". Wien (CD-ROM).

Oppermann, H.: Die 1990er Jahre in Russland. http:/www.asg.physik.unierlangen.de/europa/rus/ chronologie.html, accessed: 16.08.2001.

Piirainen, T. (1997): Towards a New Social Order in Russia. Transforming Structures and Everyday Life. Dartmouth et al.

Rajzberg, B.A./Lozovskij, L.Š./Starodubceva, E.B. (1996): Sovremennyj èkonomičeskij slovar'. Moskva.

Rathmayr, R. (2004a): Process „marketizacii“ diskursa (na primere stanovlenija koncepta „kačestvo žizni“"). In: Arutjunova N.D. (ed.) Logičeskij analiz jazyka. Jazyki èstetiki: konceptual'nye polja prekrasnogo i bezobraznogo. Moskva (in print).

Rathmayr, R.(2004b): Koncept den'gi u Peterburgskogo naselenija v načale 1990-ych godov. In: Slavica Tamperensia VI, Hg. Marja Leinonen Концепт (in print).

Simon, G. (1997): Russland auf der Suche nach seiner politischen Identität. Visionen und Wirklichkeiten, Berichte des Bundesinstituts für ostwissenschaftliche und internationale Studien, 33. Köln.

Skljarevskaja, G.N. (ed.) (1998): Tolkovyj slovar' russkogo jazyka konca XX veka. Jazykovye izmenenija. St. Peterburg.

Stepanov, J.S. (2001): Konstanty. Slovar' russkoj kul'tury. Opyt issledovanija. 2-oe izdanie. Moskva.

van Dijk, T.(1998): Ideology. A Multidisciplinary Approach. London et al. 1998.

Wodak, R.(1995): Critical linguistics and critical discourse analysis. In: Verschueren J./Östmann J.-O./Blommaert J. (eds.) Handbook of Pragmatics. Amsterdam, Philadelphia, 204-210. 